\title{
ANALISIS FAKTOR PENENTU MINAT KUNJUNG ULANG PASIEN DIABETES MELITUS DI INSTALASI RAWAT JALAN POLIKLINIK ENDOKRIN RS. PIRNGADI
}

\section{Harzalina Zilfi Amly, Juliandi Harahap, Masnelly Lubis}

Institut Kesehatan Helvetia, Dosen Departemen Kedokteran Universitas Sumatera Utara

Email: harzalinazilfi@yahoo.com, juliandi@usu.ac.id dan masnelylubis@gmail.com

\begin{tabular}{ll}
\hline INFO ARTIKEL & ABSTRAK \\
\hline Tanggal diterima: 2 Oktober & Tujuan penelitian ini untuk mengetahui faktor penentu minat \\
2020 & kunjung ulang pasien diabetes melitus di Instalasi Rawat \\
Tanggal revisi: 10 Oktober & Jalan Poliklinik Endokrin. Desain penelitian yang digunakan \\
2020 & dalam penelitian ini adalah Cross Sectional. Populasi dalam \\
Tanggal yang diterima: 20 & penelitian ini sebanyak 1879 pasien yang berobat jalan dan \\
Oktober 2020 & sampel yang diambil dengan cara purposive sampling \\
Kata Kunci: & sebanyak 95 pasien. Analisa data yang digunakan yaitu uji \\
Faktor Penentu; Minat & regresi binary logistic. Hasil penelitian menunjukkan bahwa \\
Kunjung Ulang Pasien; & jenis kelamin sig-p 0,201 $>0,05$, pekerjaan sig-p 0,987 $>$ \\
Diabetes. & 0,05, pendidikan sig-p $0,942>0,05$, pengetahuan sig-p 0,995 \\
& $>0,05$, bukti nyata sig-p $0,108>0,05$, kehandalan sig-p \\
& $0,025<0,05$, daya tanggap sig-p 0,048 $<0,05$, jaminan sig- \\
& p 0,036 $<0,05$, empati sig-p 0,022 $<0,05$ dan kepuasan \\
pasien sig-p 0,031 $<0,05$. Kesimpulan dalam penelitian ini \\
ada pengaruh kehandalan, daya tanggap, jaminan, empati \\
dan kepuasan pasien terhadap minat kunjungan ulang pasien, \\
sedangkan jenis kelamin, pekerjaan, pendidikan, \\
pengetahuan, dan bukti nyata tidak memiliki pengaruh \\
terhadap minat kunjungan ulang pasien. Diharapkan kepada \\
pihak rumah sakit untuk meningkatkan kepuasan pasien \\
menjadi lebih baik seperti memberikan rasa peduli kepada \\
pasien yang membutuhkan pelayanan kesehatan.
\end{tabular}

\section{Pendahuluan}

Undang-Undang Nomor 36 tahun 2009 tentang Kesehatan, menjelaskan bahwa kesehatan adalah keadaan setiap orang yang menunjukkan sehat baik secara fisik, mental, spiritual maupun sosial yang memungkinkan setiap orang untuk hidup produktif secara sosial dan ekonomis. Undang-Undang Dasar 1945 pasal $28 \mathrm{H}$ menyatakan bahwa setiap orang berhak mendapatkan pelayanan kesehatan, maka setiap individu, keluarga dan masyarakat berhak memperoleh perlindungan terhadap kesehatan.( Permenkes 2009)

Menurut Notoatmodjo (2010), Upaya pemeliharaan dan peningkatan kesehatan yang diwujudkan dalam suatu wadah pelayanan atau yang sering disebut dengan sarana atau pelayanan kesehatan. Pelayanan kesehatan adalah tempat atau sarana yang sering digunakan masyarakat untuk menyelenggarakan upaya kesehatan. (Notoatmodjo, S. 2010).

Penyelenggaraan pelayanan kesehatan dirumah sakit mempunyai karakteristik dan organisasi yang sangat kompleks karena berbagai jenis tenaga kesehatan dengan perangkat keilmuan yang beragam, berinteraksi satu sama lain. Rumah sakit sebagai unit pelayanan publik perlu berbenah diri dan terus meningkatkan mutu pelayanan sehingga tetap kompetitif di era globalisasi (Hadijah, 2016). Dalam menghadapi era desentralisasi dan globalisasi ekonomi, berbagai macam tantangan serta perubahan tentu akan dihadapi oleh rumah sakit. Perubahan epidemiologi penyakit, perubahan struktur demografis, perkembangan ilmu pengetahuan dan teknologi, perubahan sosio- 
ekonomi masyarakat semakin menuntut akan pelayanan kesehatan yang lebih berkualitas (Evelina, 2015).

Apabila rumah sakit tidak memperhatikan kualitas pelayanannya maka akan ditinggalkan oleh pelanggannya yang menyebabkan kerugian bagi semua pihak baik petugas, pengelola atau pemilik rumah sakit sehingga tidak mendapatkan pendapatannya. Pengguna atau pasien juga akan ikut dirugikan karena berkurang atau tidak mendapatkan layanan yang bermutu apalagi bagi masyarakat yang tidak mampu untuk memilih rumah sakit lain sesuai dengan keinginannya. Kemampuan rumah sakit dalam memyampaikan kualitas pelayanan kesehatan yang baik merupakan harapan bagi setiap masyarakat ketika datang untuk melakukan konsultasi atas permasalahan kesehatan yang sedang mereka rasakan (Henny, 2016).

Sebagai salah satu industri jasa yaitu jasa kesehatan rumah sakit, tentunya rumah sakit juga harus menjalankan fungsi-fungsi bisnis dalam manajerialnya, salah satunya adalah bagaimana menghasilkan suatu produk jasa yang bermutu atau berkualitas. Menurut (Wijaya, 2011), kualitas didefinisikan sebagai ukuran relatif kebaikan. Kualitas produk/jasa adalah keseluruhan gabungan karakteristik produk dan jasa yang dihasilkan dari pemasaran, rekayasa, produksi, dan pemeliharaan yang membuat produk/jasa dapat digunakan untuk memenuhi harapan pelanggan (Wijaya, 2011).

Peningkatan kualitas layanan yang baik tidak harus hanya berasal dari sudut pandang rumah sakit saja, tetapi juga harus berasal dari sudut pandang pasien. Rumah sakit harus mengetahui keinginan dan kebutuhan pasien. Dengan meningkatnya kualitas layanan maka diharapkan pasien akan loyal dan akan meingkatkan minat kunjung ulang pasien terhadap rumah sakit tersebut. Berdasarkan hasil penelitian yang dilakukan oleh (Lestari et al., 2017) dapat diketahui bahwa kualitas layanan memiliki pengaruh yang positif dan signifikan terhadap minat kunjungan ulang pasien di Puskesmas Mandai $(0,001>0,05)$ (Lestari et al., 2017).

Selain kualitas pelayanan, menurut Kotler dan Keller (2009), kepuasan juga dapat mempengaruhi minat pasien dalam melakukan kunjungan ulang. Kepuasan atau ketidakpuasan konsumen akan mempengaruhi perilaku konsumen, ketika rumah sakit dinilai pasien dapat memberikan kepuasan, pasien akan dapat merasa bahwa pelayanan rumah sakit ini dapat memenuhi kebutuhan akan kesehatannya sehingga akan berdampak langsung pada kunjungan ulang pasien ketika dia membutuhkan pelayanan kesehatan di kemudian hari.(8) Manfaat terciptanya kepuasan pelanggan antara lain hubungan antara perusahaan dan pelanggannya menjadi harmonis serta memberikan dasar yang baik bagi pembelian ulang (Tjiptono, 2011).

Kepuasan pasien merupakan tujuan utama rumah sakit sebagai penyedia layanan kesehatan dengan harapan agar pasien melakukan kunjungan ulang ke rumah sakit tersebut. Pasien yang puas terhadap pelayanan kesehatan akan berpeluang untuk melakukan kunjungan ulang ketika kesehatannya terganggu. Hasil penelitian yang dilakukan oleh (Helmawati \& Handayani, 2014) menunjukkan bahwa variabel kepuasan pasien terbukti memiliki pengaruh yang signifikan terhadap minat kunjungan ulang pasien di Klinik Rumah Zakat Yogyakarta (Helmawati \& Handayani, 2014).

Berdasarkan survei awal yang telah dilakukan terdapat penurunan angka kepuasan pasien dari tahun 2017 ke tahun 2018 dimana angka kepuasan pasien yang berobat jalan ke poliklinik endokrin RS Pirngadi mencapai titik terendah di bulan September 2018 yaitu $77,6 \%$, sementara target kepuasan rumah sakit adalah 90\%. Dari data tersebut dapat ditarik kesimpulan bahwa angka kepuasan pasien rawat jalan poliklinik endokrin pirngadi medan terus menurun dan masih jauh di bawah target. Tujuan penelitian ini yaitu untuk 
menganalisis Faktor Penentu Minat Kunjung Ulang Pasien Diabetes Melitus di Instalasi Rawat Jalan Poliklinik Endokrin RSUD. Pirngadi.

\section{Metode Penelitian}

Jenis penelitian adalah dengan Cross Sectional dengan tujuan untuk mengetahui faktor penentu minat berkunjung ulang pasien dengan populasi penelitian adalah 1879 pasien yang berobat jalan dan sampel yang diambil dengan cara purposive sampling sebanyak 95 pasien. Alat untuk pengumpulan data adalah observasi dan pembagian kuesioner. Data yang telah dikumpulkan diolah dengan analisis univariat, bivariat dan multivariat.

\section{Hasil dan Pembahasan}

\section{A. Hasil}

Tabel 1 diketahui bahwa dari 95 responden, sebagian besar responden memiliki umur 46-55 tahun sebanyak 40 responden $(42,1 \%)$ dan sebagian besar berjenis kelamin perempuan sebanyak 56 responden $(58,9 \%)$. Pada kategori pekerjaan sebagian besar responden bekerja yaitu sebanyak 55 responden $(57,9 \%)$. Selanjutnya pada kategori pendidikan diketahui sebagian besar responden memiliki pendidikan rendah sebanyak 50 responden $(52,6 \%)$, sedangkan pada kategori penanggung jawab pembayaran kesehatan, sebagian besar responden memiliki pembayaran jaminan kesehatan melalui asuransi sebanyak 55 responden (57,9\%).

\section{Tabel 1}

Distribusi Frekuensi Responden Berdasarkan Karakteristik Responden

\begin{tabular}{lll}
\hline \multicolumn{1}{c}{ Karakteristik } & f & \% \\
\hline Umur & & \\
36-45 Tahun & 27 & 28,4 \\
\hline 46-55 Tahun & 40 & 42,1 \\
\hline 56-65 Tahun & 28 & 29,5 \\
\hline
\end{tabular}

\begin{tabular}{lcc}
\hline $\begin{array}{l}\text { Jenis Kelamin } \\
\text { Perempuan }\end{array}$ & 56 & 58,9 \\
\hline Laki-Laki & 39 & 41,1 \\
\hline $\begin{array}{l}\text { Pekerjaan } \\
\text { Bekerja } \\
\text { Tidak Bekerja }\end{array}$ & 55 & 57,9 \\
\hline $\begin{array}{l}\text { Pendidikan } \\
\text { Tinggi }\end{array}$ & 40 & 42,1 \\
\hline Rendah & 45 & 47,4 \\
\hline Penanggung Jawab & 50 & 52,6 \\
Pembayaran Kesehatan & 40 & 42,1 \\
Pribadi & 55 & 57,9 \\
Asuransi & & \\
\hline Jumlah & $\mathbf{9 5}$ & $\mathbf{1 0 0}$ \\
\hline
\end{tabular}

Tabel 1. menunjukkan bahwa hasil uji chi-square memperlihatkan bahwa nilai signifikan probabilitas jenis kelamin adalah $p$-value $=0,522$ atau $>$ nilai 0,05 . Hal ini membuktikan jenis kelamin tidak memiliki hubungan dengan minat kunjungan ulang pasien Diabetes Melitus. Berdasarkan hasil uji chi-square memperlihatkan bahwa nilai signifikan probabilitas pekerjaan adalah $p$-value $=$ 0,697 atau $>$ nilai 0,05 . Hal ini membuktikan pekerjaan tidak memiliki hubungan dengan minat kunjungan ulang pasien Diabetes Melitus. Berdasarkan hasil uji chi-square memperlihatkan bahwa nilai signifikan probabilitas pendidikan adalah $p$-value $=0,410$ atau $>$ nilai 0,05. Hal ini membuktikan pendidikan tidak memiliki hubungan dengan minat kunjungan ulang pasien Diabetes Melitus. Berdasarkan hasil uji chi-square memperlihatkan bahwa nilai signifikan probabilitas pendidikan adalah $p$-value $=0,320$ atau $>$ nilai 0,05 . Hal ini membuktikan pengetahuan tidak memiliki hubungan dengan minat kunjungan ulang pasien Diabetes Melitus.

Berdasarkan hasil uji chi-square memperlihatkan bahwa nilai signifikan probabilitas bukti nyata adalah $p$-value $=$ 0,814 atau $>$ nilai 0,05 . Hal ini 
membuktikan bukti nyata tidak memiliki hubungan dengan minat kunjungan ulang pasien Diabetes Melitus. Berdasarkan hasil uji chi-square memperlihatkan bahwa nilai signifikan probabilitas bukti nyata adalah $p$-value $=0,000$ atau $<$ nilai 0,05 . Hal ini membuktikan kehandalan memiliki hubungan dengan minat kunjungan ulang pasien Diabetes Melitus. Berdasarkan hasil uji chi-square memperlihatkan bahwa nilai signifikan probabilitas daya tanggap adalah $p$-value $=0,000$ atau $<$ nilai 0,05 . Hal ini membuktikan daya tanggap memiliki hubungan dengan minat kunjungan ulang pasien Diabetes Melitus. Berdasarkan hasil uji chi-square memperlihatkan bahwa nilai signifikan probabilitas jaminan adalah $p$-value $=0,000$ atau $<$ nilai 0,05 . Hal ini membuktikan jaminan memiliki hubungan dengan minat kunjungan ulang pasien Diabetes Melitus. Berdasarkan hasil uji chi-square memperlihatkan bahwa nilai signifikan probabilitas empati adalah $p$-value $=$ 0,000 atau $<$ nilai 0,05 . Hal ini membuktikan empati memiliki hubungan dengan minat kunjungan ulang pasien Diabetes Melitus. Berdasarkan hasil uji chi-square memperlihatkan bahwa nilai signifikan probabilitas kepuasan pasien adalah $p$-value $=0,000$ atau $<$ nilai 0,05 . Hal ini membuktikan kepuasan pasien memiliki hubungan dengan minat kunjungan ulang pasien Diabetes Melitus di Instalasi Rawat Jalan Poliklinik Endokrin Rumah Sakit Pirngadi Medan.
Tabel 2

Hubungan Jenis Kelamin, Pekerjaan, Pendidikan, Bukti Fisik, Kehandalan, Ketanggapan, Kepastian, Empati dan Kepuasan Pasien dengan Minat Kunjungan Ulang Pasien

\begin{tabular}{|c|c|c|c|c|c|c|c|}
\hline \multirow{3}{*}{ Variabel } & \multicolumn{4}{|c|}{ Minat Kunjungan Ulang } & \multirow{2}{*}{\multicolumn{2}{|c|}{ Total }} & \multirow{3}{*}{ p-Value } \\
\hline & \multicolumn{2}{|c|}{$\begin{array}{c}\text { Kurang } \\
\text { Berminat }\end{array}$} & \multicolumn{2}{|c|}{ Berminat } & & & \\
\hline & f & $\%$ & f & $\%$ & f & $\%$ & \\
\hline \multicolumn{8}{|l|}{ Jenis Kelamin } \\
\hline Laki-Laki & 31 & 55,4 & 25 & 44,6 & 56 & 100 & 0,522 \\
\hline Perempuan & 25 & 64,1 & 14 & 35,1 & 39 & 100 & \\
\hline \multicolumn{8}{|l|}{ Pekerjaan } \\
\hline Tidak Bekerja & 25 & 62,5 & 15 & 37,5 & 40 & 100 & 0,697 \\
\hline Bekerja & 31 & 56,4 & 24 & 43,6 & 55 & 100 & \\
\hline \multicolumn{8}{|l|}{ Pendidikan } \\
\hline Rendah & 27 & 54,0 & 23 & 46,0 & 50 & 100 & 0,410 \\
\hline Tinggi & 29 & 64,4 & 16 & 35,6 & 45 & 100 & \\
\hline \multicolumn{8}{|l|}{ Pengetahuan } \\
\hline Kurang Baik & 30 & 65,2 & 16 & 34,8 & 46 & 100 & 0,320 \\
\hline Baik & 26 & 53,1 & 23 & 46,9 & 49 & 100 & \\
\hline \multicolumn{8}{|l|}{ Bukti Nyata } \\
\hline Kurang Baik & 37 & 60,7 & 24 & 39,3 & 61 & 100 & 0,814 \\
\hline Baik & 19 & 55,9 & 15 & 44,1 & 34 & 100 & \\
\hline \multicolumn{8}{|l|}{ Kehandalan } \\
\hline Kurang Baik & 51 & 92,7 & 4 & 7,3 & 55 & 100 & 0,000 \\
\hline Baik & 5 & 12,5 & 35 & 87,5 & 40 & 100 & \\
\hline \multicolumn{8}{|l|}{ Daya Tanggap } \\
\hline Kurang Baik & 47 & 78,3 & 13 & 21,7 & 60 & 100 & 0,000 \\
\hline Baik & 9 & 25,7 & 26 & 74,3 & 35 & 100 & \\
\hline \multicolumn{8}{|l|}{ Jaminan } \\
\hline Kurang Baik & 47 & 88,7 & 6 & 11,3 & 53 & 100 & 0,000 \\
\hline Baik & 9 & 21,4 & 33 & 78,6 & 42 & 100 & \\
\hline \multicolumn{8}{|l|}{ Empatt } \\
\hline Kurang Baik & 45 & 93,8 & 3 & 6,2 & 48 & 100 & 0,000 \\
\hline Baik & 11 & 23,4 & 36 & 76,6 & 47 & 100 & \\
\hline \multicolumn{8}{|l|}{ Kepuasan } \\
\hline Kurang Puas & 46 & 93,9 & 3 & 6,1 & 49 & 100 & 0,000 \\
\hline Puas & 10 & 21,7 & 36 & 78,3 & 46 & 100 & \\
\hline Total & 56 & 58,9 & 39 & 41,1 & 95 & 100 & \\
\hline
\end{tabular}

Tabel 2 menunjukkan bahwa faktor (kehandalan, daya tanggap, jaminan, empati dan kepuasan pasien) memiliki 
pengaruh yang signifikan terhadap minat kunjungan ulang pasien diabetes melitus di Instalasi Rawat Jalan Poliklinik Endokrin Rumah Sakit Pirngadi Medan.

Tabel 3

Hasil Uji Multivariat Regresi Logistik

\begin{tabular}{llll}
\hline \multicolumn{1}{c}{ Variabel } & B & Sig. & Exp(B) \\
\hline Kehandalan & 2,649 & 0,025 & 14,139 \\
\hline Daya Tanggap & 2,941 & 0,048 & 18,927 \\
\hline Jaminan & 2,750 & 0,036 & 15,636 \\
\hline Empati & 2,974 & 0,022 & 19,567 \\
\hline Kepuasan Pasien & 3,024 & 0,031 & 20,567 \\
\hline Constant & $-6,669$ & 0,002 & 0,001 \\
\hline
\end{tabular}

\section{B. Pembahasan}

1. Pengaruh Kehandalan terhadap Minat Kunjungan Ulang Pasien

Kehandalan memiliki nilai sigp $0,025<0,05$ artinya kehandalan memiliki pengaruh secara signifikan terhadap minat kunjungan ulang pasien diabetes melitus di Instalasi Rawat Jalan Poliklinik Endokrin Rumah Sakit Pirngadi Medan. Hasil nilai OR pada variabel kehandalan menunjukkan nilai OR 14,139. Artinya kehandalan yang kurang baik cenderung 14 kali lipat memiliki pengaruh terhadap kurang minatnya kunjungan ulang pasien. Nilai $\mathrm{B}=$ Logaritma Natural dari $14,139=2,649$. Oleh karena nilai B bernilai positif, maka kehandalan mempunyai pengaruh positif terhadap minat kunjungan ulang pasien.

Sejalan dengan penelitian yang dilakukan oleh Abidin tahun 2016 tentang Pengaruh Kualitas Pelayanan BPJS Kesehatan terhadap Kepuasan Pasien di Puskesmas Cempae Kota Parepare menunjukkan hasil bahwa ada pengaruh kehandalan $(\mathrm{p}=0,004)$, ketanggapan $(\mathrm{p}=0,002)$ dan empati $(p=0,006)$ terhadap kepuasan peserta
BPJS pasien rawat inap di Puskesmas Cempae Kota Parepare. Kesimpulan dari penelitian bahwa ada pengaruh kehandalan, ketanggapan dan empati terhadap kepuasan peserta BPJS pasien rawat inap di Puskesmas Cempae Kota Parepare (Abidin, 2016).

Dimensi kehandalan merupakan kemampuan untuk memberikan pelayanan yang tepat dan tepercaya. Pelayanan yang tepercaya adalah pelayanan yang konsisten dan kompeten. Penilaian persepsi kehandalan ini merupakan bagian dari dimensi Kehandalan dengan metode Servqual (Service Quality) yang dikembangkan oleh Parasuraman, Zeithaml dan Malholtra (2005) merupakan kemampuan untuk memberikan pelayanan yang akurat dan sesuai dengan janji (Asmuji, 2013).

Menurut asumsi peneliti kehandalan yang perlu ditingkatkan di poliklinik endokrin berdasarkan hasil deskripsi jawaban responden pada penelitian ini adalah prosedur penerimaan pasien dilayani secara cepat dan tepat tidak berbeli-belit serta kesiapan tenaga kesehatan melayani pasien setiap saat. Kehandalan atau reliability pelayanan akan dapat diberikan jika dapat dipercaya oleh pelanggan meliputi pelayanan harus konsisten, selain itu pelayanan yang berbelit-belit dan lamanya masa tunggu pasien dapat menentukan mutu pelayanan kesehatan karena membuat pasien merasa tidak dilayani dengan baik sehingga hal ini akan dapat menimbulkan ketidak puasan. Untuk itu hal ini perlu ditingkatkan karena keandalan sangat penting dalam membantu proses kesembuhan pasien dengan tepat dan terpercaya sehingga 
dapat memberikan pelayanan yang bermutu dan memuaskan. Usaha yang harus dilakukan dalam meningkatkan kehandalan seorang petugas kesehatan antara lain melayani pasien secara cepat dan tidak mengulur waktu, tidak membiarkan pasien menunggu lama dalam pemeriksaan kesehatannya, memberikan pelayanan yang ramah dan sopan sehingga pasien merasa nyaman serta senang terhadap pelayanan yang diberikan.

\section{Pengaruh Daya Tanggap terhadap Minat Kunjungan Ulang Pasien}

Variabel daya tanggap memiliki nilai sig- $p 0,048<0,05$ artinya daya tanggap memiliki pengaruh secara signifikan terhadap minat kunjungan ulang pasien diabetes melitus di Instalasi Rawat Jalan Poliklinik Endokrin Rumah Sakit Pirngadi Medan. Hasil nilai OR pada variabel daya tanggap menunjukkan nilai $\mathrm{OR}$ 18,927 . Artinya daya tanggap yang kurang baik cenderung 19 kali lipat memiliki pengaruh terhadap kurang minatnya kunjungan ulang pasien. Nilai B = Logaritma Natural dari $18,927=2,941$. Oleh karena nilai B bernilai positif, maka daya tanggap mempunyai pengaruh positif terhadap minat kunjungan ulang pasien.

Penelitian ini sejalan dengan penelitian yang dilakukan oleh Ambariani tahun 2014, tentang Pengaruh Kualitas Pelayanan Puskesmas Santun Lansia pada Kepuasan Pasien Lanjut Usia di Puskesmas Santun Lanjut Usia Kabupaten Bogor Jawa Barat, menunjukkan bahwa kualitas pelayanan Puskesmas Santun Lansia (dimensi bukti fisik, ketanggapan, dan perhatian) mempunyai pengaruh pada kepuasan pasien lansia $(\mathrm{p}<0,05)$.
Besar pengaruh bukti fisik 0,42 $(17,6 \%)$, ketanggapan $0,28(7,8 \%)$, dan perhatian $0,25(6,3 \%)$. Dimensi pelayanan lainnya (kehandalan dan jaminan) tidak terbukti berpengaruh $(p>0,05)$. Variabel sosio-demografik (usia dan pendidikan) berbeda signifikan dengan skor kepuasan pasien lansia $(\mathrm{p}<0,05)$. Kualitas pelayanan Puskesmas Santun Lansia dalam dimensi servqual (bukti fisik, kehandalan, ketanggapan, jaminan, dan perhatian) telah dipersepsikan memiliki kenyataan cukup baik, walaupun kualitas pelayanan yang diterima masih belum memenuhi harapan (Ambariani, 2014).

Ketanggapan merupakan bagian dari dimensi ketanggapan dengan metode Servqual (Service Quality) yang dikembangkan oleh Parasuraman, Zeithaml dan Malholtra, kesediaan untuk membantu pelanggan, merespon dan memberikan pelayanan yang cepat yang meliputi kecepatan karyawan dalam menangani keluhan pelanggan serta kesigapan karyawan dalam melayani pelanggan. Penilaian persepsi daya tanggap pada penelitian ini meliputi perawat bersikap ramah dan sopan serta perawat memperhatikan kebutuhan dan keluhan pasien. Berdasarkan penilaian tersebut sebagian besar responden merasa masih mendapatkan pelayanan kurang baik pada indikator perawat belum bersikap ramah dan sopan (Al-asaf AF, 2013).

Menurut asumsi penelitian persepsi daya tanggap yang perlu ditingkatkan pada pelayanan kesehatan adalah pelayanan yang ramah dan sopan, hal ini sangat penting dalam memberikan pelayanan kesehatan yang memuaskan pasien, karena pasien sangat membutuhkan 
dukungan dan pelayanan yang ramah dengan senyum, sapa dan salam itu akan dapat membuat pasien merasa dilayani dengan baik dan penuh rasa sabar serta tanggap sehingga akan membantu dalam proses penyembuhan. Ketanggapan dan kepekaan terhadap kebutuhan pasien akan meningkatkan mutu pelayanan kesehatan. Berdasarkan sudut pandang pengguna jasa pelayanan, mutu pelayanan kesehatan adalah pelayanan yang dapat memenuhi segala keinginan atau kebutuhan pasien secara sopan, menghargai, tanggap, dan ramah. Hubungan persepsi daya tanggap dengan kepuasan pasien merupakan hasil stimulus dan panca indera pasien dari pelayanan yang diterima akan dapat dipersepsikan sehingga nantinya akan dapat menilai mutu pelayanan, jika apa yang mereka harapkan sesuai dengan kenyataan yang mereka dapatkan, maka akan dapat memberikan kepuasan kepada pasien terhadap daya tanggap petugas kesehatan, begitu juga sebaliknya jika apa yang mereka harapkan tidak sesuai dengan kenyataan maka pasien tidak puas.

\section{Pengaruh Jaminan terhadap Minat Kunjungan Ulang Pasien}

Variabel jaminan memiliki nilai sig-p $0,036<0,05$ artinya jaminan memiliki pengaruh secara signifikan terhadap minat kunjungan ulang pasien diabetes melitus di Instalasi Rawat Jalan Poliklinik Endokrin Rumah Sakit Pirngadi Medan. Hasil nilai OR pada variabel jaminan menunjukkan nilai OR 15,636. Artinya jaminan yang kurang baik cenderung 17 kali lipat memiliki pengaruh terhadap kurang minatnya kunjungan ulang pasien. Nilai $\mathrm{B}=$ Logaritma
Natural dari $15,636=2,750$. Oleh karena nilai $\mathrm{B}$ bernilai positif, maka jaminan mempunyai pengaruh positif terhadap minat kunjungan ulang pasien.

Penelitian ini sejalan dengan penelitian yang dilakukan oleh Pratiwi, Y tahun 2018 tentang Pengaruh Kualitas Pelayanan terhadap Kepuasan Masyarakat Sebagai Pasien di Puskesmas Sering Kecamatan Medan Tembung, menunjukkan hasil bahwa kehandalan, daya tanggap, jaminan, perhatian dan bukti fisik secara simultan berpengaruh secara positif dan signifikan terhadap kepuasan masyarakat sebagai pasien. Secara parsial kehandalan dan jaminan berpengaruh secara positif dan signifikan terhadap kepuasan masyarakat sebagai pasien. Sedangkan, daya tanggap, perhatian, dan bukti fisik berpengaruh secara positif dan tidak signifikan terhadap kepuasan masyarakat sebgai pasien (Eka, 2018).

Penilaian persepsi jaminan pada penelitian ini meliputi tenaga kesehatan terdidik dan mampu melayani pasien, menjaga kerahasiaan pasien selama berada diperawatan, dan meningkatkan kepercayaan pasien serta membantu dalam proses kesembuhan pasien. Jaminan pada mutu pelayanan berkaitan dengan pengetahuan karyawan serta kemampuan mereka dalam menumbuhkan rasa percaya dan keyakinan pelanggan terhadap jasa pelayanan kesehatan (Zeithaml, V. A., A. Parasuraman, 1990).

Menurut asumsi peneliti, dimana rumah sakit perlu meningkatkan pendidikan tenaga kesehatan dan kemampuan petugas kesehatan melayani pasien karena 
pendidikan dan keterampilan dari petugas kesehatan sangat menjamin dalam membantu proses penyembuhan dari pasien, hal ini sangat mempengaruhi kepercayaan dari pasien agar nantinya pasien merasa aman dalam memperoleh pelayanan asuhan petugas kesehatan. Hasil ini sejalan dengan teori dari jaminan mutu yang mempunyai arti meyakinkan orang, mengamankan atau menjaga serta memberikan kewajaran terhadap pasien dengan menggunakan teknik-teknik sesuai dengan prosedur untuk dapat meningkatkan asuhan perawatan terhadap pasien. Dimensi jaminan merupakan hal yang sangat penting karena kesembuhan seorang pasien berada ditangan para petugas kesehatan yang menangani selama pasien dirawat, sehingga pengetahuan yang dimiliki seorang petugas kesehatan harus sesuai dengan ilmu yang mereka pelajari dan mengikuti prosedur-prosedur yang ada dalam memberikan pelayanan kesehatan karena pasien membutuhkan kesembuhan dengan tepat dan terjamin. Dalam Permenkes 71 tahun 2013 dijelaskan bahwa jaminan kesehatan kepada pasien harus dipenuhi secara baik untuk meninggakatkan kualitas pelayanan kesehatan yang diberikan. Adapun usaha yang dilakukan antara lain memberikan perlindungan kesehatan kepada pasien, memperoleh perawatan dan pemeliharaan kesehatan dan memberikan kemudahan kepada pasien untuk mendapatkan pelayanan kesehatan yang layak.

\section{Pengaruh Empati terhadap Minat Kunjungan Ulang Pasien}

Variabel empati memiliki nilai sig- $p 0,022<0,05$ artinya empati memiliki pengaruh secara signifikan terhadap minat kunjungan ulang pasien diabetes melitus di Instalasi Rawat Jalan Poliklinik Endokrin Rumah Sakit Pirngadi Medan. Hasil nilai OR pada variabel empati menunjukkan nilai OR 19,567. Artinya empati yang kurang baik cenderung 17 kali lipat memiliki pengaruh terhadap kurang minatnya kunjungan ulang pasien. Nilai $\mathrm{B}=$ Logaritma Natural dari $19,567=2,974$. Oleh karena nilai $\mathrm{B}$ bernilai positif, maka empati mempunyai pengaruh positif terhadap minat kunjungan ulang pasien.

Penelitian ini sejalan dengan yang dilakukan oleh Adawiyah, $\mathrm{R}$ tahun 2015 tentang Gambaran Kualitas Pelayanan Kesehatan di Puskesmas Sedan Kabupaten Rembang Jawa Tengah, menunjukkan bahwa kualitas pelayanan Puskesmas Sedan pada dimensi tangibles kurang memuaskan dengan skor gap -0.173, dimensi reliability kurang memuaskan dengan skor gap - 0,170, dimensi responsiveness sangat memuaskan dengan skor gap 0,125, dimensi assurance sangat memuaskan dengan skor gap 0,210, dan dimensi empathy sangat memuaskan dengan skor gap 0,050. Hasil pengukuran kualitas pelayanan Puskesmas Sedan secara umum dapat dikatakan kurang memuaskan dengan skor gap -0,032. Untuk meningkatkan kualitas pelayanan kesehatan, Puskesmas Sedan perlu memperbaiki keadaan kamar mandi, melengkapi persediaan obat, meningkatkan akurasi diagnosa dokter, dan meningkatkan ketepatan 
resep obat yang diberikan kepada pasien (Adawiyah, 2015).

Dimensi Empati (empathy) artinya, memberikan perhatian yang tulus kepada pasien yang bersifat individual atau pribadi yang berupaya dalam memahami keinginan pasien. Persepsi empati merupakan bagian dari dimensi Empati dengan metode Servqual (Service Quality) yang dikembangkan oleh Parasuraman, Zeithaml dan Malholtra (2005) yang meliputi kemudahan untuk menghubungi perusahaan, kemampuan karyawan untuk berkomunikasi dengan pelanggan dan usaha perusahaan untuk memahami kebutuhan pelanggannya. Penilaian sempati pada penelitian ini meliputi petugas kesehatan meluangkan waktu khusus untuk berkomunikasi dengan pasien, petugas kesehatan selalu mengingatkan keamanan akan menyimpan barang berharga pasien dan keluarganya, waktu untuk berkonsultasi keluarga pasien terpenuhi, dan menghibur dan memberikan dorongan kepada pasien supaya cepat sembuh dan mendoakan mereka (Zeithaml, V. A., A. Parasuraman, 1990).

Menurut asumsi peneliti maka dapat disimpulkan bahwa, kepuasan maupun ketidakpuasan pasien sangat tidak berpengaruh dengan persepsi empati pasien karena empati yang diberikan oleh petugas kesehatan dapat dirasakan secara langsung oleh pasien dari awal pelayanan sampai akhir pelayanan. Pada dasarnya setiap pasien ingin diperlakukan secara individu atau khusus, dengan demikian rasa empati petugas dalam memberikan asuhan pelayanan kesehatan merupakan alat utama dalam memenuhi harapan pasien akan perlakuan istimewa, sehingga terwujudlah kepuasan pasien terhadap pelayanan kesehatan yang mereka terima.

\section{Pengaruh Kepuasan Pasien terhadap Minat Kunjungan Ulang Pasien}

Variabel kepuasan pasien memiliki nilai sig-p $0,031<0,05$ artinya kepuasan pasien memiliki pengaruh secara signifikan terhadap minat kunjungan ulang pasien diabetes melitus di Instalasi Rawat Jalan Poliklinik Endokrin Rumah Sakit Pirngadi Medan. Hasil nilai OR pada variabel kepuasan pasien menunjukkan nilai OR 20,567. Artinya kepuasan pasien yang kurang puas cenderung 21 kali lipat memiliki pengaruh terhadap kurang minatnya kunjungan ulang pasien. Nilai $\mathrm{B}=$ Logaritma Natural dari $50,484=3,024$. Oleh karena nilai $\mathrm{B}$ bernilai positif, maka kepuasan pasien mempunyai pengaruh positif terhadap minat kunjungan ulang pasien.

Penelitian yang dilakukan oleh Aminatuzzahroh, S tahun 2014 tentang Analisis Hubungan Persepsi Pasien tentang Mutu Pelayanan Kesehatan Dengan Pemanfaatan Ulang Pelayanan Rawat Jalan di Puskesmas Poncol Kota Semarang, menunjukkan bahwa tidak ada hubungan tentang kompetensi teknik $(\mathrm{p}=0,796), \quad$ akses keterjangkauan $(\mathrm{p}=0,187)$, dan efisiensi kelangsungan pelayanan $(p=0,275), \quad$ dan ada hubungan tentang kenyamanan $(p=0,012)$, ketersediaan informasi $(\mathrm{p}=0,008), \quad$ dan hubungan antarmanusia $\quad(p=0,000) \quad$ dengan pemanfaatan ulang pelayanan rawat jalan Puskesmas Poncol.Saran untuk Puskesmas Poncol agar lebih 
meningkatkan manajemen mutu pelayanan kesehatan yang ada (Aminatuzzahroh, 2015).

Kepuasan pasien adalah tingkat perasaan pasien yang timbul sebagai akibat dari kinerja layanan kesehatan yang diperolehnya, setelah pasien membandingkan dengan apa yang diharapkannya. Aspek terpenting dalam memberikan kepuasan adalah aspek afektif yaitu perasaan pasien bahwa perawat sebagai tenaga kesehatan mendengarkan dan memahami keluhan-keluham pasien, jika hal ini tidak dapat diberikan maka akan timbul ketidak puasan (Parasuraman et al., 1988).

Menurut asumsi peneliti maka dapat disimpulkan bahwa, kepuasan maupun ketidakpuasan pasien sangat tidak berpengaruh dengan persepsi empati pasien karena empati yang diberikan oleh petugas kesehatan dapat dirasakan secara langsung oleh pasien dari awal pelayanan sampai akhir pelayanan. Pasien beralasan bahwa pelayanan yang diberikan kepada mereka masih tidak maksimal. Pasien mengungkapkan bahwa tenaga kesehatan tidak ramah, sopan dan tanggap dalam melakukan perawatan kepada mereka. Pasien juga menyayangkan pelayanan yang diberikan masih sangat lambat dan bertele-tele dan tidak sesuai dengan prosedur pelayanan kesehatan, sehingga mereka kurang puas terhadap mutu pelayanan yang diberikan dan mereka juga menambahkan bahwa apabila mereka mengalami masalah kesehatan lagi, mereka tidak berminat untuk kembali kerumah sakit itu. Pada dasarnya setiap pasien ingin diperlakukan secara individu atau khusus, dengan demikian rasa kepedulian petugas dalam memberikan asuhan pelayanan kesehatan merupakan alat utama dalam memenuhi harapan pasien akan perlakuan istimewa, sehingga terwujudlah kepuasan pasien terhadap pelayanan kesehatan yang mereka terima.

\section{Kesimpulan}

Ada pengaruh kehandalan, daya tanggap, jaminan, empati dan kepuasan pasien terhadap minat kunjungan ulang pasien, sedangkan jenis kelamin, pekerjaan, pendidikan, pengetahuan, dan bukti nyata tidak memiliki pengaruh terhadap minat kunjungan ulang pasien.

\section{BIBLIOGRAFI}

Abidin. (2016). Pengaruh Kualitas Pelayanan BPJS Kesehatan terhadap Kepuasan Pasien di Puskesmas Cempae Kota Parepare. Jurnal MKMI, 12(2), 70-75.

Adawiyah, R. (2015). Gambaran Kualitas Pelayanan Kesehatan Di Puskesmas Sedan Kabupaten Rembang Jawa Tengah. Universitas Islam Negeri Syarif Hidayatullah.

Al-asaf AF. (2013). Mutu Pelayanan Kesehatan: Perspektif Internasional. EGC.

Ambariani. (2014). Pengaruh Kualitas Pelayanan Puskesmas Santun Lansia Pada Kepuasan Pasien Lanjut Usia Di Puskesmas Santun Lanjut Usia Kabupaten Bogor. 1(1), 59-68.

Aminatuzzahroh, S. (2015). Analisis Hubungan Persepsi Pasien tentang Mutu Pelayanan Kesehatan Dengan Pemanfaatan Ulang Pelayanan Rawat Jalan di Puskesmas Poncol Kota Semarang. Universitas Negeri Semarang, 1-67.

Asmuji. (2013). Manajemen Keperawatan 
(II). Ar-Ruzz Media.

Eka, Y. G. (2018). Pengaruh Kualias Pelayanan Terhadap Kepuasan Masyrakat sebagai Pasien di Puskesmas Sering. Skripsi USU, 1-126.

Evelina, Y. (2015). Pengaruh Kinerja Pelayanan Rawat Inap Terhadap Kepuasan dan Loyalitas Pasien Rumah Saki. Jurnal.

Hadijah, H. (2016). Analisis Kualitas Pelayanan Rawat Inap di Rumah Sakit Umum Daerah Undata Palu Provinsi Sulawesi Tengah. Katalogis, 4(7).

Helmawati, T., \& Handayani, S. D. (2014). Pengaruh kualitas layanan terhadap minat kunjungan ulang yang dimediasi oleh kepuasan pasien di klinik Rumah Zakat Yogyakarta. JMMR (Jurnal Medicoeticolegal Dan Manajemen Rumah Sakit), 3(1).

Henny, S. (2016). Pengaruh Persepsi Pasien Tentang Mutu Pelayanan Terhadap Minat Kunjungan Ulang Di Klinik Spog Rumah Sakit Dr. Pirngadi Medan Tahun 2016. UIN Syarif Hidayatullah Jakarta: Fakultas Kedokteran dan Ilmu Kesehatan, 2017.

Lestari, E. D., Samsualam, S., \& Ahri, R. A. (2017). Pengaruh Kualitas Layanan Terhadap Kepuasan Dan Minat
Kunjungan Ulang Pasien Di Wilayah Kerja Puskesmas Mandai Kabupaten Maros Tahun 2017. Jurnal Ilmiah Kesehatan Diagnosis, 11(4), 423-428.

Parasuraman, A., A, V., \& Zeithaml, L. (1988). Servqual : A Multiple Item Scale For Measuring Consumer Perception Of Service Quality. Jurnal of Retailling, 64(1), 12-40.

Tjiptono, F. (2011). Pemasaran Jasa. Jawa Timur. Bayumedia Publishing.

Wijaya, T. (2011). Manajemen kualitas jasa. Jakarta: PT. Indeks, 143.

Zeithaml, V. A., A. Parasuraman, dan L. L. B. (1990). Delivering Quality Services. Free Press.

\section{Copyright holder:}

Harzalina Zilfi Amly, Juliandi Harahap, Masnelly Lubis (2020)

First publication right:

Jurnal Health Sains

This article is licensed under:

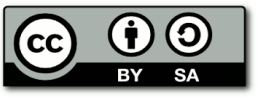

